\title{
Effects of dry period length on metabolic status, fertility, udder health, and colostrum production in 2 cow breeds
}

\author{
E. Andrée O'Hara, ${ }^{1 *}$ R. Båge,${ }^{2}$ U. Emanuelson, ${ }^{2}$ and K. Holtenius ${ }^{1}$ \\ ${ }^{1}$ Department of Animal Nutrition and Management, Swedish University of Agricultural Sciences, 75007 Uppsala, Sweden \\ ${ }^{2}$ Department of Clinical Sciences, Swedish University of Agricultural Sciences, 75007 Uppsala, Sweden
}

\begin{abstract}
Shortening the dry period improves postpartum energy balance, which has potential positive effects on metabolic health. This concept has been mainly studied in Holstein cows. The aim of this study was to assess the effect of a short dry period of $4 \mathrm{wk}$, compared with a standard dry period of $8 \mathrm{wk}$, on the metabolic status, progesterone profiles, health, and colostrum quality of dairy cows of 2 breeds, Swedish Red (SR) and Swedish Holstein $(\mathrm{SH})$, not treated with antibiotics at dry off. The IgG uptake in calves was also studied to reflect the colostrum quality when shortening the dry period. Cows of both SH and SR were blocked by breed and parity and then randomly allocated to a short dry period of $4 \mathrm{wk}(4 \mathrm{~W}, \mathrm{n}=43)$ or a conventional dry period of $8 \mathrm{wk}(8 \mathrm{~W}, \mathrm{n}=34)$. Blood samples were collected wk $-8,-4,-2,-1$ and $1,2,3,4,6,9$, and 12 relative to calving. Prepartum, cows with a 4 -wk dry period had higher concentrations of nonesterified fatty acids and lower concentrations of insulin-like growth factor-1 and insulin than $8 \mathrm{~W}$ cows. Postpartum, plasma concentration of nonesterified fatty acids was lower, whereas plasma insulin and insulin-like growth factor-1 tended to be higher for $4 \mathrm{~W}$ cows than for $8 \mathrm{~W}$ cows. Plasma concentration of $\beta$-hydroxybutyrate did not differ between dry period lengths. Swedish Holstein cows with a $4 \mathrm{~W}$ dry period responded with a lower concentration of insulin prepartum than SR and $\mathrm{SH}$ on an $8 \mathrm{~W}$ dry period. The dry period length had no effect on the proportion of disturbed progesterone profiles; disturbed progesterone profiles occurred in $30 \%$ of the $4 \mathrm{~W}$ cows and $47 \%$ of the $8 \mathrm{~W}$ cows. In this trial, only $48.8 \%$ of the SR cows had a normal progesterone profile, which differed from the SH where $76.5 \%$ had a normal profile. Fertility-related diseases (endometritis, pyometra, anestrus, ovarian cyst) did not differ between the 2 dry period groups: $21 \%$ in the $8 \mathrm{~W}$ group versus $12 \%$ in the
\end{abstract}

Received April 4, 2018.

Accepted August 30, 2018.

*Corresponding author: lisa.ohara@slu.se
$4 \mathrm{~W}$ group, whereas mastitis tended to be more common: $26 \%$ of the $4 \mathrm{~W}$ cows versus $9 \%$ of the $8 \mathrm{~W}$ cows. A short dry period resulted in less colostrum but with a higher content of protein and somatic cell count. Calves were fed colostrum from their dam, and the IgG and total protein in plasma did not differ between calves to mothers with different a dry period length. Shortening the dry period could improve metabolic status in cows of both SH and SR breed postpartum, without compromising the colostrum quality. Health and progesterone profiles were not affected by the dry period length for SH or SR in this study.

Key words: short dry period, metabolism, fertility, colostrum

\section{INTRODUCTION}

The modern dairy cow is often high yielding. The 2 major breeds in Sweden, Swedish Red (SR) and Swedish Holstein (SH), produce 9,747 and 10,452 kg of ECM per year, respectively (Växa, 2017). Most studies examining the effects of dry period (DP) length on the metabolism of dairy cows have been performed using the Holstein breed. Thus, it is not clear whether cows of dual-purpose breeds, such as the SR, respond in the same way to shortened DP. The high-yielding SH breed might be more suitable for a short DP.

The rapidly increasing milk yield after parturition in these breeds increases the metabolic load of the cow and the disease incidence also peaks immediately after parturition (Ingvartsen, 2006). High milk yield may result in a severe negative energy balance (NEB), which is known to influence fertility (Wathes et al., 2007); a long interval between parturition and first ovulation and luteal activity, and a low conception rate, are reported to be related to NEB (de Vries and Veerkamp, 2000). One way to reduce NEB, and thereby to alleviate the strain on the metabolism after calving, is to shorten or omit the DP (Gümen et al., 2005; Chen et al., 2015a). The main reason for improved energy balance (EB) on shortening the DP is decreased milk production postpartum without affecting DMI (Rastani 
et al., 2005; van Knegsel et al., 2014; Andrée O'Hara et al., 2018). The cow's metabolic state and the degree of mobilization of adipose tissue are partly reflected by plasma concentrations of nonesterified fatty acids (NEFA; Pullen et al., 1989) and are related to EB (Ingvartsen and Andersen, 2000). Most studies (Watters et al., 2008; Klusmeyer et al., 2009), but not all (Weber et al., 2015), report a reduction in plasma concentration of NEFA in response to a short DP of 32 to $34 \mathrm{~d}$. Shortening the DP induces an increase in plasma concentration of insulin in early lactation (Rastani et al., 2005; Weber et al., 2015), whereas varying responses in glucose and BHB have been reported (Klusmeyer et al., 2009; Weber et al., 2015).

Some studies indicate that fertility traits are improved when the DP is shortened. For example, the interval from calving to first ovulation is reported to be shorter when the DP is reduced from 55 to $34 \mathrm{~d}$ (Watters et al., 2009). Another study found no improvement in first service conception rate, services per conception rate, or conception rate on shortening the DP from 49 to 28 d (Pezeshki et al., 2008). Cows in NEB with a prolonged interval to first ovulation have been found to have increased levels of NEFA and reduced levels of IGF-1, which can lead to impaired follicular growth, reduced estradiol synthesis, and delayed ovulation (Wathes et al., 2007).

It is unclear how shortening the DP affects udder health. For example, in a retrospective study, Kuhn et al. (2006) found an increase in postpartum SCC in milk, whereas Gulay et al. (2003) observed a tendency for lower SCC and van Knegsel et al. (2014) found no differences in SCC between short and conventional DP length.

The influence of DP length on mastitis incidence has been examined in only a few studies, which show that short DP length generally does not influence mastitis incidence (as reviewed by van Knegsel et al., 2013). However, the effect of short DP on SCC and mastitis incidence has been investigated in even fewer studies where cows were not treated with preventive dry cow therapy (Van Hoeij et al., 2018).

Calves are born agammaglobulinemic because of the physiology of the bovine placenta and are instead provided with immunoglobulins from colostrum. Uptake of immunoglobulins is influenced by the time of feeding after birth, amount, and how it is administrated to the calf, and also by the immunoglobulin content in the colostrum (Weaver et al., 2000). So far, most studies on the effect of DP on colostrum quality have shown no or a limited reduction in colostrum volume and $\operatorname{IgG}$ content (Rastani et al., 2005; Klusmeyer et al., 2009; Shoshani et al., 2014). In one study on uptake of immunoglobulins in the calf, Mayasari et al. (2015) found no differences in immunoglobulin uptake in calves born to mothers with short or conventional DP length.

The objective of the present study was to evaluate how metabolic status, fertility (in this case progesterone profiles), udder health, colostrum, and IgG uptake in the calf were affected by shortening the DP in dairy cows of 2 breeds. We hypothesized that the SR cows would be less suited for a short DP than SH cows and that the metabolic status would be improved in the $4 \mathrm{~W}$ cows.

\section{MATERIALS AND METHODS}

The work was carried out during the winter feeding period in 2 consecutive years (2012-2014) at the Swedish Livestock Research Centre, Swedish University of Agricultural Sciences, Lövsta, Uppsala, Sweden. Mean herd annual milk production per cow was $10,514 \mathrm{~kg}$ of ECM for the SH cows and 9,263 $\mathrm{kg}$ of ECM for the SR cows during 2012-2013 and 11,143 kg of ECM for the $\mathrm{SH}$ cows and 9,734 $\mathrm{kg}$ of ECM for the SR during 2013-2014. The experimental design and all handling of animals were approved by Uppsala Ethics Committee, Sweden (C217812/13).

\section{Animals and Management}

Multiparous cows of SR $(\mathrm{n}=43)$ and $\mathrm{SH}(\mathrm{n}=34)$ were blocked by breed and parity and then randomly allocated to 2 different treatments: a conventional DP of $8 \mathrm{wk}(\mathbf{8 W})$ or a short DP of $4 \mathrm{wk}(\mathbf{4 W})$. The cows were allocated to the 2 treatments, respectively, well in advance of entering the trial. Several of them were excluded because they did not fulfil the inclusion criteria as defined below. This resulted in uneven treatment groups. Actual mean DP \pm standard error length was $58.8 \pm 0.7 \mathrm{~d}$ for the $8 \mathrm{~W}$ group and $30.7 \pm$ $0.7 \mathrm{~d}$ for the $4 \mathrm{~W}$ group. The cows were studied from 10 wk before expected calving to 12 wk postpartum. All cows included had an udder disease score $<5$ and yielded at least $15 \mathrm{~kg}$ of milk/d at 10 wk prepartum. Neither dry cow antibiotic therapy nor teat sealants were administered at drying-off or during the DP. The information about udder disease score was obtained from the Swedish Official Milk Recording Scheme and is based on individual SCC from 3 consecutive monthly test milkings, corrected for milk yield, breed, parity, and DIM. The scale runs from 0 to 9 and expresses the probability of IMI, where each class increase the risk by $10 \%$ so $>5$ indicates $>50 \%$ probability (Brolund, 1990).

Cows subjected to the $4 \mathrm{~W}$ treatment were milked until 4 wk before the expected calving date, and cows in the $8 \mathrm{~W}$ group were milked until 8 wk before expected calving date. Milking was carried out in an automatic 
rotary system (DeLaval AMR, Tumba, Sweden) twice a day, at 0530 and $1530 \mathrm{~h}$. Due to farm practicalities, 13 of the cows were milked in a voluntary milking system (DeLaval) for the last 6 to $12 \mathrm{wk}$ of the study. All cows were kept indoors in a loose-housing system, with free access to cubicles with rubber mats and wood shavings. At drying off, cows were moved to a drying-off pen after morning milking (d 1), milked again once on d 3 and on $\mathrm{d} 6$, and if milk yield $>25 \mathrm{~kg} / \mathrm{d}$ in the week before drying off, again on d 8. Artificial insemination was performed by trained personnel approximately 12 $\mathrm{h}$ after detected estrus. The concentrate allowance was gradually reduced, over the course of $1 \mathrm{wk}$, to zero 2 $\mathrm{d}$ before drying off. Feeding and feed composition has been published earlier as well as milk yield, milk composition, DMI, BCS, and EB (Andrée O'Hara et al., 2018).

\section{Blood Sampling and Analysis}

Blood samples were taken $8,4,2$, and 1 wk prepartum and $1,2,3,4,6,9$, and 12 wk postpartum. Blood was harvested from the coccygeal artery or vein into heparinized $10-\mathrm{mL}$ vacuum tubes with lithium heparin as anticoagulant (BD Vacutainer, Becton, Dickinson and Company, Franklin Lakes, NJ) at approximately 1000 $\mathrm{h}$ each time. The samples were centrifuged at $+4^{\circ} \mathrm{C}$ within $1 \mathrm{~h}$ of sampling and plasma samples were stored at $-20^{\circ} \mathrm{C}$ until further analysis. After thawing, plasma samples were analyzed for glucose using enzymatic colorimetric tests (Glucose LiquiColor, Human, Wiesbaden, Germany) and spectrophotometry (Ultrospec K, Boule Nordic, Huddinge, Sweden). The concentration of insulin was analyzed using a commercial enzyme immunoassay method adapted for bovines (Mercodia Ultrasensitive Bovine Insulin ELISA, Mercodia AB, Uppsala, Sweden). The concentration of NEFA was analyzed using an enzymatic colorimetric test (NEFA C, Wako Chemicals GmbH, Neuss, Germany). The concentration of IGF-1 was determined using a commercial enzyme immunoassay (Bovine Insulin-like Growth Factor 1 ELISA catalog no. KT-18278, Kamaya Medical Company, Seattle, WA). The concentration of BHB in plasma was analyzed with a kinetic enzymatic method (RANBUT, Randox Laboratories Limited, Crumlin, UK) and was only analyzed for the 45 cows sampled during yr 2.

\section{Milk Progesterone Analysis and Progesterone Profiles}

The concentration of progesterone was determined in milk samples collected twice weekly from 2 to $12 \mathrm{wk}$ postpartum using a commercial ELISA (Ridgeway Sci- ence Ltd., Alvington, UK). Progesterone was then plotted for each cow and classified into 4 different profiles according to Petersson et al. (2006): (A) normal cyclicity, first rise in progesterone before d 56 postpartum, followed by regular cyclicity; (B) delayed cyclicity with low progesterone for at least $56 \mathrm{~d}$ after calving; (C) cessation of cyclicity, with a normal start but cyclicity interrupted with low progesterone for at least $14 \mathrm{~d}$; and (D) prolonged luteal phase, with a normal start but with extended periods of high progesterone of at least $20 \mathrm{~d}$. Milk samples for progesterone were missing for part or all of the period for 2 cows, resulting in no progesterone profiles for these cows. Commencement of luteal activity was defined as a rise in progesterone above $5 \mathrm{ng} / \mathrm{mL}$.

Visual estrus detection was performed 3 times daily.

\section{Health}

The cows were checked daily for disease detection and received veterinary treatment when needed. All veterinary treatments were recorded for each cow. Dinolytic vet (Orion Pharma AB Animal Health, Danderyd, Sweden) was used to treat anestrus cows and cows diagnosed with endometritis and pyometra. Clinical mastitis cases received selective antibiotic treatment based on laboratory bacterial culture results, and if necessary, nonsteroidal anti-inflammatory drugs. Mastitis cases were defined as cows diagnosed with and treated for mastitis, based on the following clinical signs: fever, swollen udder, pain, and changed color of milk. Treatment decisions were based on these clinical mastitis signs in combination with a raise in udder health class of 1 to 2 scores and a SCC $>800,000$ cells $/ \mathrm{mL}$ of milk.

Milk samples $(25 \mathrm{~mL})$ were collected once a month from an afternoon milking and the following morning once every $4 \mathrm{wk}$ into tubes prepared with bronopol and stored at $4^{\circ} \mathrm{C}$. Milk SCC was analyzed using fluorescence-based cell counting (Fossomatic 5000, Foss, Hillerød, Denmark). Somatic cell count on the regular milk testing closest to $8 \mathrm{wk}$ prepartum was on average 81,500 cells $/ \mathrm{mL}$ of milk for the $4 \mathrm{~W}$ cows and 65,400 cells $/ \mathrm{mL}$ of milk for the $8 \mathrm{~W}$ cows.

\section{Colostrum and Calves}

Colostrum was weighed manually for the first 5 milkings, and a milk sample of $25 \mathrm{~mL}$ was collected during the first and fifth milkings. Colostrum was analyzed for composition of fat and protein by infrared Fourier transform spectroscopy (MilkScan FT120 Foss) and SCC as described above.

All calves were fed 2.5 to $3 \mathrm{~L}$ of colostrum with a nipple bucket within $12 \mathrm{~h}$ of birth, and all calves except 
one were fed within 6 h. Calves were weighed after their first meal. Blood plasma was harvested once from the jugular vein during d 2 to 9 and once during d 56 to 64 , at approximately $1100 \mathrm{~h}$. The samples were centrifuged at $+4^{\circ} \mathrm{C}$ within $1 \mathrm{~h}$ of sampling and the plasma samples were stored at $-20^{\circ} \mathrm{C}$ until further analysis. After thawing, the concentration of $\operatorname{IgG}$ in plasma from calves was determined using a 2-sited ELISA (Bovine IgG ELISA, Kamiya Biomedical Company) on a combined shaker and plate reader (Multiskan FC, Thermo Fisher Scientific, Waltham, MA). Blood plasma samples from calves were analyzed for total protein in plasma immediately after centrifuging, using an optical refractometer (Master Refractometer, Atago, Tokyo, Japan). One calf from a SR cow in the $4 \mathrm{~W}$ treatment died at birth. Of the remaining 44 calves, 15 had to be excluded from the data set regarding total protein content in plasma, due to missing information about the amount of colostrum fed or to the calf being fed colostrum from a cow other than the mother.

\section{Statistical Analysis}

Data were analyzed with the statistical software SAS 9.3 (SAS Institute Inc., Cary, NC). The PROC MIXED model with repeated measurements was used to study plasma metabolites in prepartum lactation wk $-8,-4$, -2 , and -1 , and then postpartum lactation wk $1,2,3$, $4,6,9$, and 12 , in 2 separate data sets. In the plasma figures, however, all measured weeks were included. The following model was used:

$$
\begin{aligned}
\mathrm{Y} & =\text { treatment }+ \text { breed }+ \text { parity class } \\
& + \text { lactation week }+ \text { cow }+ \text { year },
\end{aligned}
$$

where cow and year are random effects and $\mathrm{Y}$ is the dependent variable. Multiparous cows (parity 3 or older after parturition) formed one parity class (parity $\geq 3$ ) and all cows approaching their second parturition another (parity 2). Interactions between treatment and breed, treatment and parity class, and treatment and lactation week were included in all models, but taken out of the model when not significant $(P>0.05)$. Because observations were made several times on the same animal, the model also estimated the correlation in time using a spatial power correlation structure. Least squares means were calculated using the SAS statement LSMEANS/PDIFF. The data on SCC, insulin, and plasma metabolites NEFA and IGF-1 were $\log _{10}$-transformed before statistical analyses to achieve normally distributed residuals. The 3 milk sample analyses per cow were statistically evaluated with the same mixed model as presented above and the cell count had to be $\log _{10}$-transformed to achieve normally distributed residuals. Interactions between treatment and breed, treatment and parity class, and treatment and lactation week were included in the model, but were all taken out of the model because they were not significant $(P>0.05)$.

Progesterone profiles were divided into 2 groups, normal (A) or disturbed (B-D), and treatment effects were then evaluated by a $\chi^{2}$ test provided by OpenEpi (www.OpenEpi.com). The same program was used to evaluate proportion of animals suffering from mastitis or fertility-related diseases.

Colostrum parameters and days to first rise in progesterone were statistically evaluated with the same mixed model as presented above, only without lactation week, cow, and the correlation structure for time. For calves, total protein in plasma and IgG uptake were statistically evaluated by comparing only treatments with the Wilcoxon rank sum test in SAS 9.3 because the residuals were not normally distributed and transformation did not improve their distribution.

\section{RESULTS}

\section{Plasma Metabolites}

Treatment, breed, and parity had no effect on concentrations of plasma glucose or BHB. The concentration of IGF-1 was higher prepartum, and lower in the first week postpartum, in $8 \mathrm{~W}$ cows than in $4 \mathrm{~W}$ cows (Figure 1). Swedish Red cows had higher concentrations of IGF-1 than SH cows (Table 1). Younger cows had higher concentrations of IGF-1 postpartum than multiparous cows (parity 2: $84.3 \mathrm{ng} / \mathrm{mL}$; parity $\geq 3$ : $73.8 \mathrm{ng} / \mathrm{mL} ; P<0.01)$.

The concentration of insulin in plasma varied over weeks (Figure 1) and an interaction was observed between treatment and week $(<0.05)$ in $8 \mathrm{~W}$ cows, whereby insulin was higher 4 wk prepartum and lower 6 wk postpartum. Insulin differed between breeds postpartum, with SR cows having higher concentrations of insulin in plasma than SH cows (Table 1).

The plasma concentration of NEFA was affected by week (Tables 1 and 2) and an interaction was observed between treatment and week $(P<0.02)$, with NEFA being numerically highest for $8 \mathrm{~W}$ SH cows during the second week after calving (Figure 1).

\section{Fertility}

In terms of progesterone profile (Table 3), cows in the $4 \mathrm{~W}$ group had a $36 \%$ lower risk of a disturbed progesterone profile than cows in the $8 \mathrm{~W}$ group but no difference was observed between $4 \mathrm{~W}$ and $8 \mathrm{~W}$ in the 


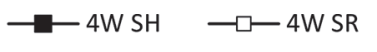

-8 WSH $\quad--0-8 W S R$
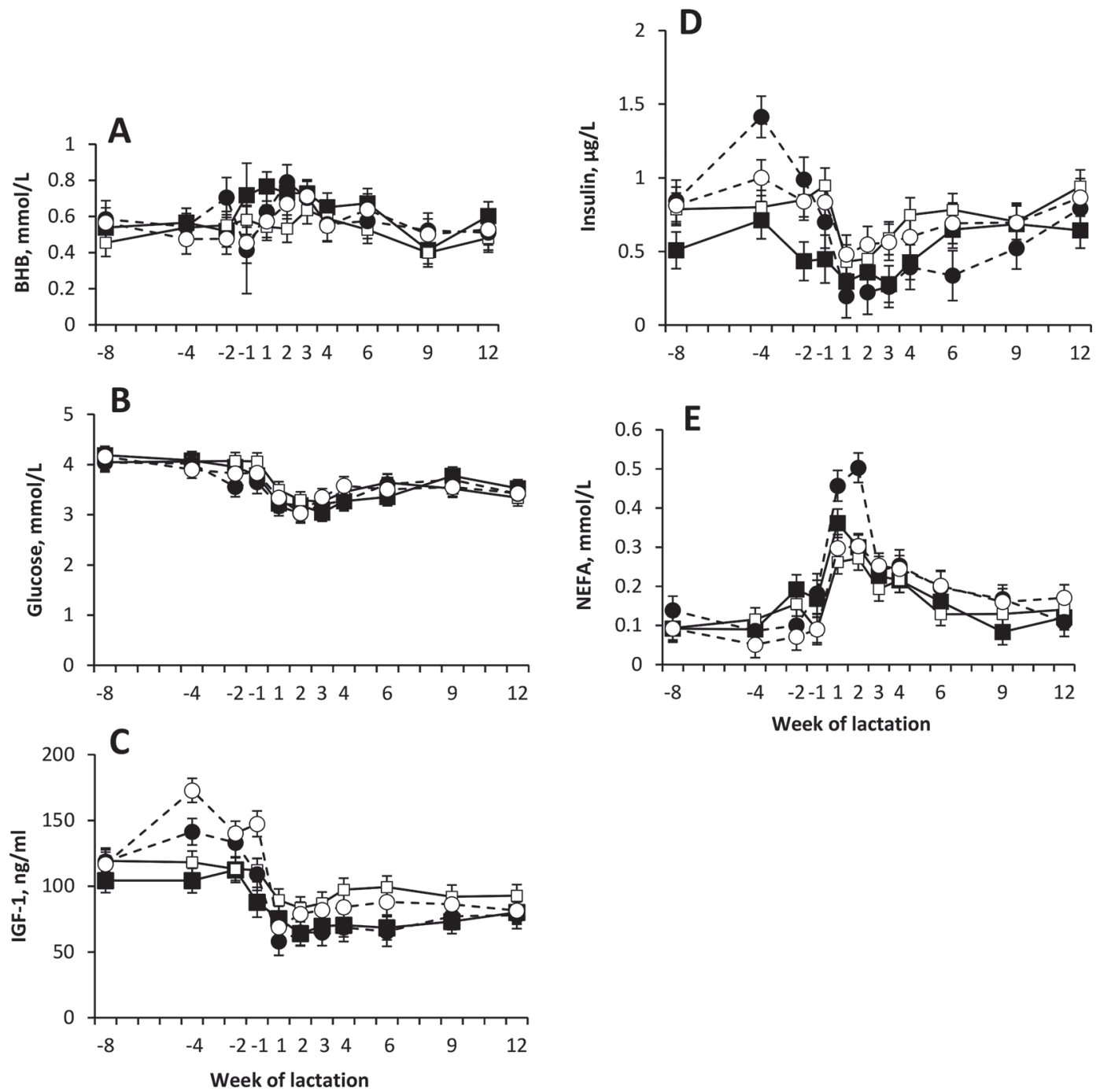

Figure 1. Least squares means ( $\pm \mathrm{SE}$ ) of blood plasma concentrations of BHB (A), glucose (B), IGF-1 (C), insulin (D), nonesterified fatty acids (NEFA; E) for the treatments with a 4-wk (4W) and 8-wk (8W) dry period in 2 cow breeds: Swedish Red (SR) and Swedish Holstein (SH). Sampling started 8 wk before expected calving and continued to 12 wk postpartum [ $4 \mathrm{~W} \mathrm{SH}, \mathrm{n}=20 ; 4 \mathrm{~W}$ SR, n $=23 ; 8 \mathrm{~W}$ SH, $\mathrm{n}=15 ; 8 \mathrm{~W}$ SR, $\mathrm{n}=19$ for BHB (A); $4 \mathrm{~W} \mathrm{SH}, \mathrm{n}=13 ; 4 \mathrm{~W} \mathrm{SR}, \mathrm{n}=13 ; 8 \mathrm{~W} \mathrm{SH}, \mathrm{n}=8 ; 8 \mathrm{~W} \mathrm{SR}, \mathrm{n}=11(\mathrm{~B}, \mathrm{C}, \mathrm{D}$, and $\mathrm{E})]$.

proportion of cows with normal progesterone profiles [15/32 (47\%) of $4 \mathrm{~W}$ cows vs. $13 / 43(30 \%)$ of $8 \mathrm{~W}$ cows].

Among the disturbed profiles, profile D (i.e., prolonged luteal phase) was the most common for cows in both the $4 \mathrm{~W}$ and $8 \mathrm{~W}$ groups. Three cows in the $8 \mathrm{~W}$ group and 11 cows in the $4 \mathrm{~W}$ group became pregnant within d 62 to 84 of lactation (within the trial period), but no cow had a prolonged luteal phase because of pregnancy. One cow in the $8 \mathrm{~W}$ group did not start cycling within the $12 \mathrm{wk}$ and thus fell into progesterone profile B. The SH cows had a larger proportion of normal progesterone profiles than did the SR cows
(SH $77 \%$ vs. SR $49 \% ; P<0.05$ ). No differences were observed between treatment groups and breeds when studying commencement of luteal activity $(P>0.05)$.

\section{Udder Health}

Somatic cell count did not differ $(P<0.1)$ between $8 \mathrm{~W}$ cows and $4 \mathrm{~W}$ cows (back-transformed LSM 81,000 and 120,000 cells $/ \mathrm{mL}$, respectively) and was not affected by breed or parity. However, cows in the $4 \mathrm{~W}$ group had higher SCC at the first and fifth milking. Mastitis tended to be more common among $4 \mathrm{~W}$ cows, 
whereas fertility-related diseases were numerically more common among $8 \mathrm{~W}$ cows (Table 4 ). Other wounds and diseases were in the $4 \mathrm{~W}$ group; one cow was diagnosed with bloat, one was lame, one had an udder wound, and one had another smaller wound. In the $8 \mathrm{~W}$ group, one cow had a calving-related problem, one had a retained placenta, one cow had an udder wound, and one had another smaller wound.

\section{Calves and Colostrum Quality}

Cows with a 4-wk DP produced less colostrum but had a higher protein content (Table 5). Immunoglobulin $\mathrm{G}$ and total protein in plasma did not differ significantly between calves born to mothers with a 4- or 8-wk DP $(P>0.4$; Table 6$)$.

\section{DISCUSSION}

\section{Metabolites}

The plasma concentration of NEFA was higher in $8 \mathrm{~W}$ cows than in $4 \mathrm{~W}$ cows in early lactation. Many previous studies also report reduced concentrations of NEFA in plasma in cows after a short DP (e.g., Pezeshki et al., 2007; Watters et al., 2008; Klusmeyer et al., 2009). It is reasonable to assume that the lower concentration of NEFA in cows with a short DP was related to less severe NEB, although the relationship between EB and plasma NEFA appears to be rather weak (Reist et al., 2002; Wylie et al., 2008). The $4 \mathrm{~W}$ cows in the present study showed a less severe dip in postpartum NEB and they returned to positive EB $9 \mathrm{wk}$ before the $8 \mathrm{~W}$ cows (Andrée O'Hara et al., 2018). It is well documented that high concentrations of NEFA in blood plasma in early lactating cows are related to increased risk of metabolic diseases (LeBlanc et al., 2005; Ospina et al., 2010). A suggested cut-off value for increased risk has been set to $0.7 \mathrm{mmol} / \mathrm{L}$ in early lactation (Ospina et al., 2010; Chapinal et al., 2011). In the present study, only 3 cows from each DP treatment had concentrations of NEFA above $0.7 \mathrm{mmol} / \mathrm{L}$ (data not shown). Thus it is not evident from the present study that a short DP reduces the risk of metabolic diseases, bearing in mind the low number of animals. Before parturition, insulin concentration was lower in $4 \mathrm{~W}$ cows than in cows with a conventional 8-wk DP. It is reasonable to assume that the shorter DP, and thereby the prolonged lactation prepartum, prevented the rise in insulin observed in $8 \mathrm{~W}$ cows. As expected, insulin tended to be higher in the $4 \mathrm{~W}$ group after parturition. Lipolysis in adipose tissues of those cows was presumably reduced, which in turn contributed to the observed lower concentration of NEFA in plasma. Insulin prepartum was lower in 
A SHORT DRY PERIOD, METABOLISM, AND FERTILITY

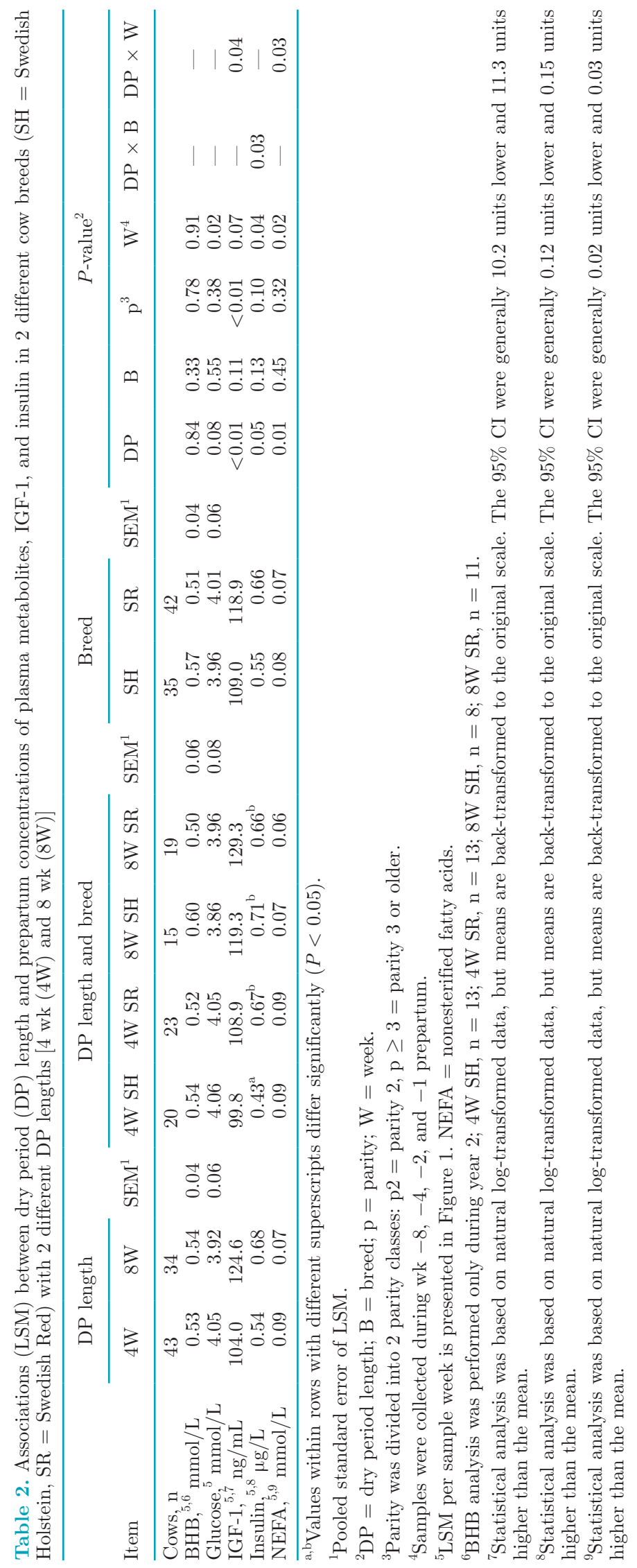




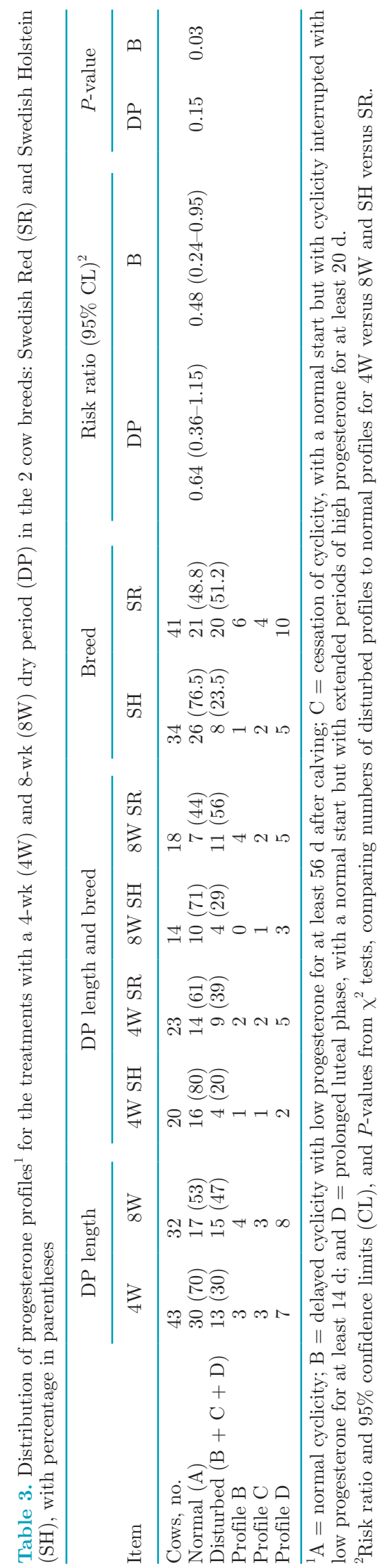

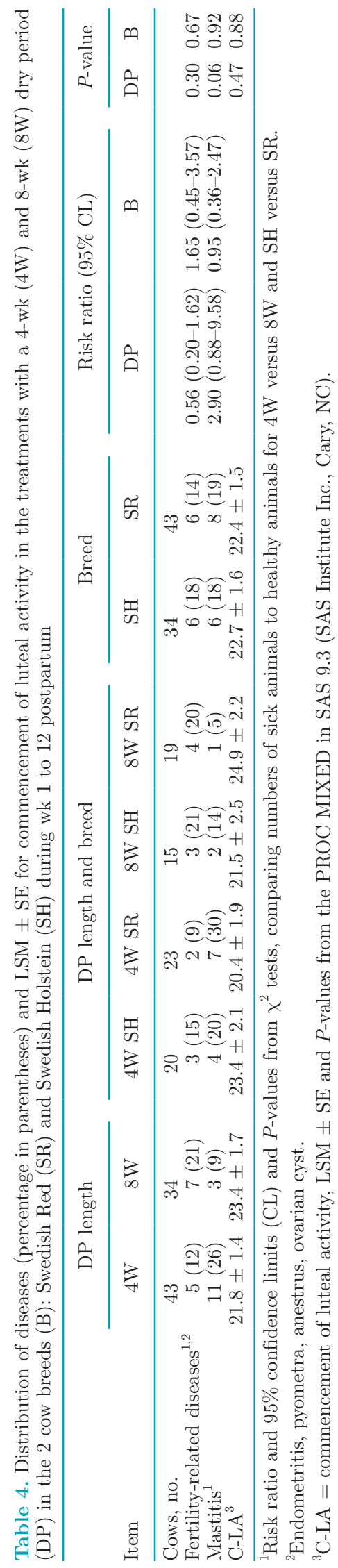


the $4 \mathrm{~W}$ SH breed than in the $8 \mathrm{~W}$ SH breed, whereas it did not differ between the SR cows. It has previously been shown that cows with longer lactations than 300 $\mathrm{d}$ increasingly partition nutrients toward tissue gain rather than milk production aided by insulin (Marett et al., 2015). It is possible that this redistribution of nutrients was less prominent in $\mathrm{SH}$ cows than in in the dual-purpose SR breed. Indeed, SR cows with a short DP yielded about $12 \%$ less milk than $\mathrm{SH}$ with a similar DP did (Andrée O'Hara et al., 2018). After parturition, the concentration of insulin in plasma of SR cows was higher than in SH cows. The basal level of insulin is apparently not related to body condition in cows during the postpartal period (Holtenius et al., 2003; Jaakson et al., 2018). Thus, the higher concentration of insulin in SR cows was probably a breed effect and not related to higher body condition. In line with our results Nyman et al. (2008) reported that SR cows had higher insulin levels than SH cows in early lactation. Ntallaris et al. (2017) observed that SR cows tended to have higher insulin and to be in a less deep NEB after calving compared with $\mathrm{SH}$ and the authors suggested that SR cows prioritized milk production to a lesser extent. However, this suggestion is not supported by the present study because EB postpartum was virtually equal between breeds (Andrée O'Hara et al., 2018). Only a few interactions between parity and DP length were found, unlike in other studies (Annen et al., 2004; Kuhn et al., 2006; Pezeshki et al., 2007; Sawa et al., 2015). Few metabolic differences were found between cows approaching their second calving as multiparous cows with a shortened DP. Second-parity cows had higher concentrations of IGF-1 than multiparous cows, in agreement with observations in younger cows (Wathes et al., 2007). Glucose and BHB were not affected by DP, as also shown in a systematic review by van Knegsel et al. (2013). Postpartum SR cows had a higher plasma concentration of insulin than $\mathrm{SH}$ cows. The SR cows were also over-conditioned to a greater extent than SH cows (Andrée O'Hara et al., 2018).

\section{Fertility}

In this study, postpartum IGF-1 tended $(P=0.06)$ to be higher in cows subjected to a 4-wk DP compared with an 8-wk DP, possibly explaining the tendency for lower incidence of disturbed progesterone profiles among $4 \mathrm{~W}$ cows. A previous study have shown that cows with lower IGF-1 levels after calving take longer to resume their estrous cycle (Wathes et al., 2007).

Among the disturbed progesterone profiles, a prolonged luteal phase was the most common disturbance. Similarly, Chen et al. (2015b) found numerically fewer disturbances among cows with a 30-d DP than cows 
Table 6. Associations between dry period (DP) length [4 wk (4W), $8 \mathrm{wk}(8 \mathrm{~W})]$ and plasma content in the calf in 2 different cow breeds $(\mathrm{SH}=$ Swedish Holstein, $\mathrm{SR}=$ Swedish Red), mean $\pm \mathrm{SD}$

\begin{tabular}{|c|c|c|c|c|c|c|}
\hline \multirow[b]{2}{*}{ Item $^{1}$} & \multicolumn{2}{|c|}{ DP length } & \multicolumn{2}{|c|}{ Breed } & \multicolumn{2}{|c|}{$P$-value } \\
\hline & $4 \mathrm{~W}$ & $8 \mathrm{~W}$ & $\mathrm{SH}$ & SR & DP & B \\
\hline Total protein 1 calves, no. & 15 & 14 & 14 & 15 & & \\
\hline Total protein $1, \mathrm{~g} / \mathrm{L}$ & $58.2 \pm 5.4$ & $56.5 \pm 5.3$ & $59.6 \pm 7.8$ & $55.3 \pm 5.0$ & 0.61 & 0.12 \\
\hline Total protein 2 calves, no. & 13 & 14 & 14 & 13 & & \\
\hline Total protein $2, \mathrm{~g} / \mathrm{L}$ & $58.0 \pm 2.9$ & $58.9 \pm 4.2$ & $57.3 \pm 3.5$ & $59.7 \pm 3.5$ & 0.41 & 0.08 \\
\hline IgG calves, no. & 11 & 12 & 12 & 11 & & \\
\hline $\mathrm{IgG}, \mathrm{g} / \mathrm{L}$ & $8.0 \pm 4.9$ & $7.4 \pm 4.2$ & $8.8 \pm 5.1$ & $6.5 \pm 3.4$ & 0.79 & 0.26 \\
\hline
\end{tabular}

${ }^{1}$ Samples were taken during d 2 to 9 (protein 1 and $\operatorname{IgG}$ ) or d 56 to 64 (protein 2) of life.

with a $60-\mathrm{d}$ DP and also that prolonged luteal phase was the most frequent disturbed profile. Despite less cyclicity disturbances and a tendency for fewer fertility-related diseases in $4 \mathrm{~W}$ cows than in $8 \mathrm{~W}$ cows, the commencement of luteal activity was not significantly different, and varied by less than $2 \mathrm{~d}$, despite the higher $\mathrm{EB}$, higher IGF-1, and lower concentrations of NEFA in 4W cows. Gümen et al. (2005) and Chen et al. (2015b) also did not observe any differences in days to luteal activity when the DP was shortened or omitted, whereas Watters et al. (2009) found that cows with a shortened DP had fewer days to first ovulation. The SR cows in our study had an unexpectedly high rate of disturbed progesterone profiles. Atypical profiles and delayed cyclicity have been shown to be related to NEB, great loss in BW, and increases in fertility-related diseases (Petersson et al., 2006), none of which was observed in SR cows in the present study. The high BCS in SR cows (Andrée O'Hara et al., 2018) could be a reason for their poorer reproduction performance (Roche et al., 2007).

\section{Udder Health}

The proportion of cows diagnosed with mastitis postpartum was approximately 3 -fold higher among $4 \mathrm{~W}$ cows compared with $8 \mathrm{~W}$ cows; however, mastitis had only a tendency to be more common among $4 \mathrm{~W}$ cows. Furthermore, the SCC in milk collected during 3 milkings at 12 wk postpartum was numerically higher in $4 \mathrm{~W}$ cows and the SCC at the first and fifth milkings postpartum was higher in the $4 \mathrm{~W}$ group. This finding was somewhat unexpected because DP length, normal or short, was reported in several studies not to affect udder health (Rastani et al., 2005; Watters et al., 2008; Klusmeyer et al., 2009). In the present study, SCC was calculated as an average of 3 measures over $12 \mathrm{wk}$ and should therefore be interpreted with caution. However, in contrast with previous studies, the cows in the present study were not treated with antibiotics at drying off. van Hoeij et al. (2018) studied a short $(30 \mathrm{~d})$ DP versus no DP in cows not treated with preventive antibiotics at drying off and found that the DP length did not affect the SCC in early lactation. However, their study did not include cows with a conventional DP length, so their results are difficult to compare with ours. Although a shorter DP could decrease milk yield at drying off, and thereby reduce the risk of IMI at calving (Rajala Schultz et al., 2005), a 4-wk DP may not be long enough for the mammary tissues to adapt to the coming lactation (Capuco et al., 1997), especially not in this setup where the dry off procedure claimed a few days of the DP. Thus a 4-wk DP might not only lead to reduced milk production, but possibly also to an increased risk of IMI during the DP (Oliver and Sordillo, 1989). This in turn might increase the risk of mastitis postpartum (Green et al., 2002). It is possible that a short DP is more hazardous if cows are not treated with antibiotics at drying off. de Vries et al. (2016) observed increased concentrations of proteins involved in host defense and cell generation in colostrum from cows not treated with antibiotics at drying off and subjected to a 4-wk DP compared with a conventional 8-wk DP.

\section{Colostrum Quality and Calves}

The $4 \mathrm{~W}$ cows produced less colostrum, but colostrum quality was not affected, confirming findings in other studies (Rastani et al., 2005; Watters et al., 2008; Klusmeyer et al., 2009; Cermakova et al., 2014; Mayasari et al., 2015). The IgG content in colostrum was not analyzed, but the higher protein content in colostrum of $4 \mathrm{~W}$ cows than of $8 \mathrm{~W}$ cows presumably reflects higher IgG content (Fleenor and Stott, 1980). The concentration of $\operatorname{Ig} \mathrm{G}$ in plasma showed no difference between calves born to cows subjected to a 4- or 8-wk DP.

\section{CONCLUSIONS}

A 4-wk DP improved metabolic status, as reflected by lower plasma NEFA concentration in early lactation compared with an 8-wk DP. However, the concentra- 
tions of insulin, glucose, and BHB were not affected by shortening DP length. Generally, no breed differences were present in response to DP length, but the concentration of insulin was higher in SR cows before calving. The incidence of mastitis during the first $12 \mathrm{wk}$ after calving had a tendency to be higher among cows subjected to a 4-wk DP. Cows with a 4-wk DP yielded a lower volume of colostrum with a higher protein and fat content. The IgG content in plasma did not differ in calves that received milk from cows subjected to a 4- or 8-wk DP.

\section{ACKNOWLEDGMENTS}

The authors acknowledge the Swedish Farmers' Foundation for Agricultural Research (Stockholm) for funding this project.

\section{REFERENCES}

Andrée O'Hara, E., A. Omazic, I. Olsson, R. Båge, U. Emanuelson, and K. Holtenius. 2018. Effects of dry period length on milk production and energy balance in two cow breeds. Animal 12:508-514. https://doi.org/10.1017/S1751731117001987.

Annen, E. L., R. J. Collier, M. A. McGuire, J. L. Vicini, J. M. Ballam, and M. J. Lormore. 2004. Effect of modified dry period length and bovine somatotropin on yield and composition of milk from dairy cows. J. Dairy Sci. 87:3746-3761. https://doi.org/10.3168/ jds.S0022-0302(04)73513-4.

Brolund, L. 1990. Cellhaltens tekniska utnyttjande i kokontrollen (Technical utilization of cell count in the milk-recording service). Pages 40-41 in Animal Health 1988/89. Swedish Association for Livestock Breeding and Production, Eskilstuna, Sweden.

Capuco, A. V., R. M. Akers, and J. J. Smith. 1997. Mammary growth in Holstein cows during the dry period: Quantification of nucleic acids and histology. J. Dairy Sci. 80:477-487. https://doi.org/10 .3168/jds.S0022-0302(97)75960-5.

Cermakova, J., V. Kudrna, M. Simeckova, A. Vyborna, P. Dolezal, and J. Illek. 2014. Comparison of shortened and conventional dry period management strategies. J. Dairy Sci. 97:5623-5636. https:/ /doi.org/10.3168/jds.2013-7499.

Chapinal, N., M. Carson, T. F. Duffield, M. Capel, S. Godden, M. Overton, J. E. P. Santos, and S. J. LeBlanc. 2011. The association of serum metabolites with clinical disease during the transition period. J. Dairy Sci. 94:4897-4903. https://doi.org/10.3168/jds $.2010-4075$.

Chen, J., J. Gross, H. A. van Dorland, G. J. Remmelink, R. M. Bruckmaier, B. Kemp, and A. T. M. van Knegsel. 2015a. Effects of dry period length and dietary energy source on metabolic status and hepatic gene expression of dairy cows in early lactation. J. Dairy Sci. 98:1033-1045. https://doi.org/10.3168/jds.2014-8612.

Chen, J., N. Soede, H. A. van Dorland, G. J. Remmelink, R. M. Bruckmaier, B. Kemp, and A. T. M. van Knegsel. 2015b. Relationship between metabolism and ovarian activity in dairy cows with different dry period lengths. Theriogenology 84:1387-1396. https:// doi.org/10.1016/j.theriogenology.2015.07.025.

de Vries, M. J., and R. F. Veerkamp. 2000. Energy balance of dairy cattle in relation to milk production variables and fertility. J. Dairy Sci. 83:62-69. https://doi.org/10.3168/jds.S0022-0302(00)74856-9.

de Vries, R., M. Brandt, Å. Lundh, K. Holtenius, K. Hettinga, and M. Johansson. 2016. Short communication: Influence of shortening the dry period of Swedish dairy cows on plasmin activity in milk. J. Dairy Sci. 99:9300-9306. https://doi.org/10.3168/jds.2016 -11502 .
Fleenor, W. A., and G. H. Stott. 1980. Hydrometer test for estimation of immunoglobulin concentration in bovine colostrum. J. Dairy Sci. 63:973-977. https://doi.org/10.3168/jds.S0022-0302(80)83034 $-7$.

Green, M. J., L. E. Green, G. F. Medley, Y. H. Schukken, and A. J. Bradley. 2002. Influence of dry period bacterial intramammary infection on clinical mastitis in dairy cows. J. Dairy Sci. 85:25892599. https://doi.org/10.3168/jds.S0022-0302(02)74343-9.

Gulay, M. S., M. J. Hayen, K. C. Bachman, T. Belloso, M. Liboni, and H. H. Head. 2003. Milk production and feed intake of Holstein cows given short (30-d) or normal (60-d) dry periods. J. Dairy Sci. 86:2030-2038. https://doi.org/10.3168/jds.S0022-0302(03)73792 $-8$.

Gümen, A., R. R. Rastani, R. R. Grummer, and M. C. Wiltbank. 2005. Reduced dry periods and varying prepartum diets alter postpartum ovulation and reproductive measures. J. Dairy Sci. 88:2401-2411. https://doi.org/10.3168/jds.S0022-0302(05)72918 -0 .

Holtenius, K., S. Agenäs, C. Delavaud, and Y. Chilliard. 2003. Effects of feeding intensity during the dry period. 2. Metabolic and hormonal responses. J. Dairy Sci. 86:883-891. https://doi.org/10 $.3168 /$ jds.S0022-0302(03)73671-6.

Ingvartsen, K. L. 2006. Feeding- and management-related diseases in the transition cow: Physiological adaptations around calving and strategies to reduce feeding-related diseases. Anim. Feed Sci. Technol. 126:175-213. https://doi.org/10.1016/j.anifeedsci.2005 .08.003.

Ingvartsen, K. L., and J. B. Andersen. 2000. Integration of metabolism and intake regulation: A review focusing on periparturient animals. J. Dairy Sci. 83:1573-1597. https://doi.org/10.3168/jds .S0022-0302(00)75029-6.

Jaakson, H., P. Karis, K. Ling, A. Ilves-Luht, J. Samarütel, M. Henno, I. Jõudu, A. Waldmann, E. Reimann, P. Pärn, R. M. Bruckmaier, J. J. Gross, T. Kaart, M. Kass, and M. Ots. 2018. Adipose tissue insulin receptor and glucose transporter 4 expression, and blood glucose and insulin responses during glucose tolerance tests in transition Holstein cows with different body condition. J. Dairy Sci. 101:752-766. https://doi.org/10.3168/jds.2017-12877.

Klusmeyer, T. H., A. C. Fitzgerald, A. C. Fabellar, J. M. Ballam, R. A. Cady, and J. L. Vicini. 2009. Effect of recombinant bovine somatotropin and a shortened or no dry period on the performance of lactating dairy cows. J. Dairy Sci. 92:5503-5511. https://doi .org/10.3168/jds.2009-2390.

Kuhn, M. T., J. K. Hutchison, and H. D. Norman. 2006. Effects of length of dry period on yields of milk fat and protein, fertility and milk somatic cell score in the subsequent lactation of dairy cows. J. Dairy Res. 73:154-162. https://doi.org/10.1017/ S0022029905001597.

LeBlanc, S. J., K. E. Leslie, and T. F. Duffield. 2005. Metabolic predictors of displaced abomasum in dairy cattle. J. Dairy Sci. 88:159-170. https://doi.org/10.3168/jds.S0022-0302(05)72674-6.

Marett, L. C., M. J. Auldist, P. J. Moate, W. J. Wales, K. L. Macmillan, F. R. Dunshea, and B. J. Leury. 2015. Response of plasma glucose, insulin, and nonesterified fatty acids to intravenous glucose tolerance tests in dairy cows during a 670-day lactation. J. Dairy Sci. 98:179-189. https://doi.org/10.3168/jds.2014-8205.

Mayasari, N., G. de Vries Reilingh, M. G. Nieuwland, G. J. Remmelink, H. K. Parmentier, B. Kemp, and A. T. van Knegsel. 2015. Effect of maternal dry period length on colostrum immunoglobulin content and on natural and specific antibody titers in calves. J. Dairy Sci. 98:3969-3979. https://doi.org/10.3168/jds.2014-8753.

Ntallaris, T., P. Humblot, R. Bàge, Y. Sjunnesson, J. Dupont, and B. Berglund. 2017. Effect of energy balance profiles on metabolic and reproductive response in Holstein and Swedish Red cows. Theriogenology 90:276-283. https://doi.org/10.1016/j.theriogenology .2016.12.012.

Nyman, A.-K., U. Emanuelson, K. Holtenius, K. L. Ingvartsen, T. Larsen, and K. Persson Waller. 2008. Metabolites and immune variables associated with somatic cell counts of primiparous dairy cows. J. Dairy Sci. 91:2996-3009. https://doi.org/10.3168/jds.2007 -0969 . 
Oliver, S. P., and L. M. Sordillo. 1989. Approaches to the manipulation of mammary involution. J. Dairy Sci. 72:1647-1664. https:// doi.org/10.3168/jds.S0022-0302(89)79277-8.

Ospina, P. A., D. V. Nydam, T. Stokol, and T. R. Overton. 2010. Evaluation of nonesterified fatty acids and $\beta$-hydroxybutyrate in transition dairy cattle in the northeastern United States: Critical thresholds for prediction of clinical diseases. J. Dairy Sci. 93:546554. https://doi.org/10.3168/jds.2009-2277.

Petersson, K. J., H. Gustafsson, E. Strandberg, and B. Berglund. 2006. Atypical progesterone profiles and fertility in Swedish dairy cows. J. Dairy Sci. 89:2529-2538. https://doi.org/10.3168/jds.S0022 -0302(06)72328-1.

Pezeshki, A., J. Mehrzad, G. R. Ghorbani, B. De Spiegeleer, R. J. Collier, and C. Burvenich. 2008. The effect of dry period length reduction to 28 days on the performance of multiparous dairy cows in the subsequent lactation. Can. J. Anim. Sci. 88:449-456. https: //doi.org/10.4141/CJAS08012.

Pezeshki, A., J. Mehrzad, G. R. Ghorbani, H. R. Rahmani, R. J. Collier, and C. Burvenich. 2007. Effects of short dry periods on performance and metabolic status in Holstein dairy cows. J. Dairy Sci. 90:5531-5541. https://doi.org/10.3168/jds.2007-0359.

Pullen, D. L., D. L. Palmquist, and R. S. Emery. 1989. Effect on days of lactation and methionine hydroxy analog on incorporation of plasma fatty acids into plasma triglycerides. J. Dairy Sci. 72:4958. https://doi.org/10.3168/jds.S0022-0302(89)79079-2.

Rajala-Schultz, P. J., J. S. Hogan, and K. L. Smith. 2005. Short communication: Association between milk yield at dry-off and probability of intramammary infections at calving. J. Dairy Sci. 88:577-579. https://doi.org/10.3168/jds.S0022-0302(05)72720-X.

Rastani, R. R., R. R. Grummer, S. J. Bertics, A. Gümen, M. C. Wiltbank, D. G. Mashek, and M. C. Schwab. 2005. Reducing dry period length to simplify feeding transition cows: Milk production, energy balance, and metabolic profiles. J. Dairy Sci. 88:1004-1014. https://doi.org/10.3168/jds.S0022-0302(05)72768-5.

Reist, M., D. Erdin, D. Von Euw, K. Tschuemperlin, H. Leuenberger, Y. Chilliard, H. M. Hammon, C. Morel, C. Philipona, and Y. Zbinden. 2002. Estimation of energy balance at the individual and herd level using blood and milk traits in high-yielding dairy cows. J. Dairy Sci. 85:3314-3327. https://doi.org/10.3168/jds.S0022 -0302(02)74420-2.

Roche, J. R., K. A. Macdonald, C. R. Burke, J. M. Lee, and D. P. Berry. 2007. Associations among body condition score, body weight, and reproductive performance in seasonal-calving dairy cattle. J. Dairy Sci. 90:376-391. https://doi.org/10.3168/jds.S0022 -0302(07)72639-5.

Sawa, A., S. Krężel-Czopek, and M. Bogucki. 2015. Dry period length as related to milk yield and SCC during the first month of subsequent lactation. Ann. Anim. Sci. 15:155-163. https://doi.org/10 .2478/aoas-2014-0051.
Shoshani, E., S. Rozen, and J. J. Doekes. 2014. Effect of a short dry period on milk yield and content, colostrum quality, fertility, and metabolic status of Holstein cows. J. Dairy Sci. 97:2909-2922. https://doi.org/10.3168/jds.2013-7733.

van Hoeij, R. J., T. J. G. M. Lam, R. M. Bruckmaier, J. Dijkstra, G. J. Remmelink, B. Kemp, and A. T. M. van Knegsel. 2018. Udder health of dairy cows fed different dietary energy levels after a short or no dry period without use of dry cow antibiotics. J. Dairy Sci 101:4570-4585. https://doi.org/10.3168/jds.2017-13448.

van Knegsel, A. T. M., G. J. Remmelink, S. Jorjong, V. Fievez, and B. Kemp. 2014. Effect of dry period length and dietary energy source on energy balance, milk yield, and milk composition of dairy cows. J. Dairy Sci. 97:1499-1512. https://doi.org/10.3168/jds.2013-7391.

van Knegsel, A. T. M., S. G. A. van der Drift, J. Čermákováac, and B. Kemp. 2013. Effects of shortening the dry period of dairy cows on milk production, energy balance, health, and fertility: A systematic review. Vet. J. 198:707-713. https://doi.org/10.1016/j.tvjl .2013 .10 .005 .

Växa. 2017. Cattle statistics 2017. Uppsala, Sweden

Wathes, D. C., M. Fenwick, Z. Cheng, N. Bourne, S. Llewellyn, D. G. Morris, and R. Fitzpatrick. 2007. Influence of negative energy balance on cyclicity and fertility in the high producing dairy cow. Theriogenology 68:S232-S241. https://doi.org/10.1016/j .theriogenology.2007.04.006.

Watters, R. D., J. N. Guenther, A. E. Brickner, R. R. Rastani, P. M Crump, P. W. Clark, and R. R. Grummer. 2008. Effects of dry period length on milk production and health of dairy cattle. J. Dairy Sci. 91:2595-2603. https://doi.org/10.3168/jds.2007-0615.

Watters, R. D., M. C. Wiltbank, J. N. Guenther, A. E. Brickner, R. R. Rastani, P. M. Fricke, and R. R. Grummer. 2009. Effect of dry period length on reproduction during the subsequent lactation. J Dairy Sci. 92:3081-3090. https://doi.org/10.3168/jds.2008-1294.

Weaver, D. M., J. W. Tyler, D. C. VanMetre, D. E. Hostetler, and G. M. Barrington. 2000. Passive transfer of colostral immunoglobulins in calves. J. Vet. Intern. Med. 14:569-577. https://doi.org/10 $.1111 /$ j.1939-1676.2000.tb02278.x.

Weber, C., B. Losand, A. Tuchscherer, F. Rehbock, E. Blum, W. Yang, R. M. Bruckmaier, P. Sanftleben, and H. M. Hammon. 2015. Effects of dry period length on milk production, body condition, metabolites and hepatic glucose metabolism in dairy cows. J. Dairy Sci. 98:1772-1785. https://doi.org/10.3168/jds.2014-8598.

Wylie, A. R. G., S. Woods, A. F. Carson, and M. McCoy. 2008. Periprandial changes in metabolite and metabolic hormone concentrations in high-genetic-merit dairy heifers and their relationship to energy balance in early lactation. J. Dairy Sci. 91:577-586. https: //doi.org/10.3168/jds.2007-0388. 